\title{
A new spider species of the genus Carrbotus Thorell, 1891 (Aranei: Salticidae: Salticini) from Western Ghats of India
}

\author{
Новый вид пауков из рода Carrbotus Thorell, 1891 (Aranei: \\ Salticidae: Salticini) из Западных Гат Индии
}

\section{Puthoor Pattammal Sudhin ${ }^{1}$, Karunnappilli Shamsudheen Nafin ${ }^{1,4}$, John T.D. Caleb ${ }^{2}$, Ambalaparambil Vasu Sudhikumar ${ }^{1,5}$ П.П. Судхин ${ }^{1,3}$, К.Ш. Нафин ${ }^{1,4}$, Аж.Т.А. Калеб², А.В. Судхикумар ${ }^{1,5}$}

\footnotetext{
${ }^{1}$ Centre for Animal Taxonomy and Ecology, Department of Zoology, Christ College (Autonomous), Irinjalakuda 680125, Kerala, India. Email: ${ }^{4}$ nafinks5@gmail.com, 5 avsudhi@rediffmail.com

${ }^{2}$ Division of Biodiversity, Entomology Research Institute, Loyola College (Autonomous), Chennai, 600034, Tamil Nadu, India. E-mail: caleb87woodgate@gmail.com

${ }^{3}$ Corresponding author. E-mail: sudhinpp@gmail.com
}

KEY WORDS: Araneae, jumping spider, description, distribution, Wayanad Wildlife Sanctuary, Kerala.

КЛЮЧЕВЫЕ СЛОВА: Araneae, паук-скакунчик, описание, распространение, заповедник дикой природы Ваянад, Керала.

ABSTRACT: A new species of the jumping spider genus Carrhotus Thorell, 1891, C. tholpettyensis sp.n. $\left(\sigma^{\top}+\right)$ is diagnosed and described from the Wayanad Wildlife Sanctuary, Western Ghats, Kerala, India. Detailed morphological descriptions, diagnoses and illustrations of the copulatory organs of both sexes are provided. A map depicting the current distribution of the genus in India is also included.

How to cite this paper: Sudhin P.P., Nafin K.S., Caleb J.T.D., Sudhikumar A.V. 2021. A new spider species of the genus Carrhotus Thorell, 1891 (Aranei: Salticidae: Salticini) from Western Ghats of India // Arthropoda Selecta. Vol.30. No.4. P.551-556. doi: 10.15298/arthsel.30.4.11

PЕЗЮМЕ: Диагностирован и описан новый вид паука-скакунчика из рода Carrhotus Thorell, 1891, C. tholpettyensis sp.n. ( $\left.\bigcirc^{7}+\right)$ из заповедника дикой природы Ваянад, Западные Гаты, Керала, Индия. Приводятся детальные описания, диагнозы и иллюстрации копулятивных органов обоих полов. Также дана карта распространения рода в Индии.

\section{Introduction}

The genus Carrhotus was proposed by Thorell in 1891, with Plexippus viduus C.L. Koch, 1846 as the type species. Members of this genus are pale brown salticids varying in size, from stout to large, and occurring mainly in the Oriental region [Jastrzębski, 2009]. The genus currently contains 32 described species worldwide [WSC, 2021], of which six are known from India: C. andhra Caleb, 2020, C. assam Caleb, 2020, C. sannio (Thorell, 1877), C. silanthi Caleb, 2020, C. tristis Thorell, 1895, and C. viduus (C.L. Koch, 1846) [Prószyński, 1992; Caleb et al., 2020; WSC, 2021]. The purpose of this paper is to diagnose, describe and illustrate a new species Carrhotus tholpettyensis sp.n. $\left(\sigma^{7}+\right)$ collected from the moist deciduous forests of the Wayanad Wildlife Sanctuary in Kerala's Western Ghats, one of the world's biodiversity hotspots [Myers et al., 2000]. The current geographic distribution of all Carrhotus species in India is also mapped.

\section{Materials and methods}

Photographs of live specimens were taken with a Canon EOS 5D Mark-III using Canon EF 100mm f/2.8 Macro USM lens, Canon MP-E 65mm 1-5x Macro Lens and Canon MT-24EX Macro Twin Lite Flash. Spiders were collected by beating vegetation, and the collected specimens were stored in $70 \%$ ethanol. A morphological examination was undertaken under a Leica M205 C stereomicroscope. Digital images were taken by means of Leica DMC4500 digital camera attached to Leica M205 C stereomicroscope, with the software package Leica Application Suite (LAS), version 4.3.0. LAS montage facility. All measurements are in $\mathrm{mm}$. Distribution maps were prepared by using the online mapping software SimpleMappr [Shorthouse, 2010]. Measurement data for palps and legs are as follows: total length [femur, patella, tibia, metatarsus (except palp), tarsus]. The terminology follows Reiskind [1969], for leg spination the system adopted follows Bossellaers \& Jocque [2000]. The studied specimens are deposited in the Centre for Animal Taxonomy and Ecology (CATE), Department of Zoology, Christ College (Autonomous), Irinjalakuda, Kerala, India.

Abbreviations used in the text and figures are as follows: ALE - anterior lateral eyes, AME - anterior median eyes, $\mathrm{C}$ - cymbium, $\mathrm{CO}$ - copulatory opening, do - dorsal, $\mathrm{E}$ embolus, FD - fertilization duct, $\mathrm{pl}$ - prolateral, PLE posterior lateral eyes, PME - posterior median eyes, plv - 

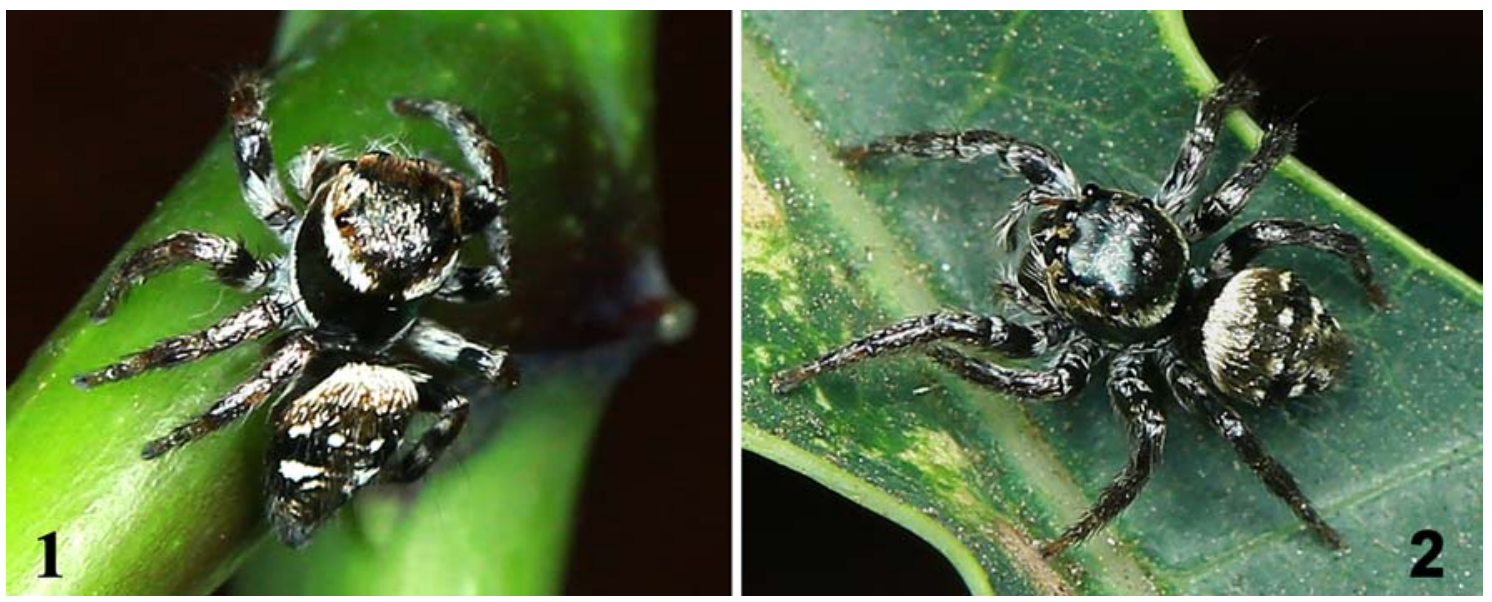

Figs 1-2. General appearance of Carrhotus tholpettyensis sp.n. from the Wayanad Wildlife Sanctuary, Kerala, India: 1 - female, dorsal view; 2 - male, dorsal view.

Рис. 1-2. Общий вид Carrhotus tholpettyensis sp.n. заповедника дикой природы Ваянад, Западные Гаты, Керала, Индия: 1 самка, вид сверху; 2 - самец, вид снизу.

prolateral-ventral, rl — retrolateral, RTA — retrolateral tibial apophysis, rlv — retrolateral-ventral, $\mathrm{v}$ - ventral.

\section{Taxonomy}

Carrhotus Thorell, 1891

Type species: Plexippus viduus C.L. Koch, 1846

\section{Carrhotus tholpettyensis sp.n. Figs 1-17, Map.}

Carrhotus viduus (nec C.L. Koch, 1846; misidentified): Prószyński, 2009: 158, figs 19-23 ( $\left.\sigma^{7}+\right)$, the specimens from the Museum für Naturkunde, Leibniz Institute for Research on Evolution and Biodiversity at the Humboldt University Berlin, Germany; not examined.

TYPE. Holotype $O^{7}$ (CATE, 8711A) from India, Kerala, Wayanad District, Tholpetty Range, the Wayanad Wildlife Sanctuary $\left(11^{\circ} 95^{\prime} 17.23^{\prime \prime N}, 76^{\circ} 05^{\prime} 94.9^{\prime \prime E}\right), 838 \mathrm{~m}$ a.s.1., 21.01.2016, P.P. Sudhin \& K.S. Nafin. Paratype: INDIA: 1 (CATE, 8711B), together with the holotype.

ETYMOLOGY. The specific epithet is an adjective derived from the name of the forest range (Tholpetty) from where the type series was collected.

DIAGNOSIS. C. tholpettyensis sp.n. is most similar to C. viduus (C.L. Koch, 1846), from which it can be distinguished by the following combination of characters: male abdomen without longitudinal stripes (a pair of white longitudinal stripes in $C$. viduus); embolus with a pointed tip directed at 11 o'clock position (blunt tip directed at 12 o'clock in C. viduus); RTA curved (broad and slightly bent in $C$. viduus); the laterally diverging copulatory ducts in the female (shorter and sub-parallel in C. viduus) (cf. Figs 3, 5, 9-17 with figs. 57, 61-64, 77, 78, 82 in Caleb et al., [2020]).

COMMENTS. Prószyński [2009] illustrated the specimens collected apparently from Sri Lanka, from the Museum für Naturkunde, the Leibniz Institute for Research on Evolution and Biodiversity at the Humboldt University (Berlin, Germany), which were incorrectly identified as Eugasmia barbata Karsch, 1880 (now Carrhotus b.). Yet, he mentioned that the studied male resembles that of $C$. viduus, with minor differences in the proportions of palpal organ, and also pointed out that the female has a distinct epigynal structure. Freshly collected specimens from the Wayanad Wildlife Sanctuary are identical to those studied by Proszsynski in having the similar abdominal pattern, the pointed embolus, short and curved RTA in the male, and the copulatory openings placed along the medial axis and the length and conformation of the copulatory ducts in the female to those illustrated by Prószyński [2009], indicating that both sets of specimens are indeed conspecific (cf. Figs 9-17 with figs 19-23 in Prószyński [2009]). Specimens from India and China seem to have also been misidentified as $C$. viduus. The illustrations by Peng et al. [1993] show a close similarity with those described here (cf. Figs 9-17 with figs 75, 76, 78, 79, 81-83 in Peng et al. [1993]). Yet, the illustrations of C. viduus from Maharashtra, India appear to be rather similar to those of $C$. silanthi Caleb, 2020 (cf. fig. 7 in Prószyński [1992] with figs 44, 48 in Caleb et al. [2020]). These problems require special attention in the future and can be resolved by a re-examination of the pertinent material.

DISTRIBUTION. Only the type locality (Map).

DESCRIPTION. MALE. (Holotype, CATE 8711A) (Figs 2, 3-5, 9-11, 14-15): Measurements. Body length 5.97. Carapace length 3.04, width (at the middle) 2.37. Abdomen length 2.80, width (at the middle) 2.10. Ocular area length 1.25, width 1.85. Eye diameters: AME 0.52, ALE 0.25, PME 0.05, PLE 0.20. Eye interdistances: AME-ALE 0.12, PME-PME 1.63, ALE-ALE 1.40, PME-PLE 0.32, PLEPLE 1.59, ALE-PLE 0.76, AME-AME 0.05. Clypeus height 0.21 . Length of chelicera 1.72. Measurement of palp and legs: palp $2.48[1.00,0.37,0.38,0.73]$, leg I 7.94 [2.10, $1.14,2.05,1.38,0.82]$, II 5.17 [1.68, 0.81, 1.12, 0.91, 0.65], III $5.41[1.89,0.78,1.11,0.96,0.67]$, IV 5.23 [1.66, 0.78, $1.07,1.07,0.65]$. Leg formula: 1342 . Leg spination: femur I pl 1 rl 1 do 1, II pl 2 rl 2 do 1, III-IV pl 3 rl 2 do 1; patella I plv 1 rlv 1 , II-IV rl 1 pl 1; tibia I pl 2 rl 2 plv 2 rlv 2 , II pl 3 rl 2 do 1 rlv 3 plv 3, III-IV pl 3 rl 3 do 1 plv 2 rlv 2; metatarsus I-II pl 2 rl 2 rlv 2 plv 2 , III pl 2 rl 2 do 1 plv 2 rlv 2, IV pl 3 rl 3 do 1 plv 2 rlv 2; tarsus I-IV spineless. General appearance as in Figs 1, 3-5. Carapace reddish brown, covered with white hairs, lateral margin with narrow dark brown lines (Figs 3, 5); eye field dark brown, darker around eyes except for AMEs; anterior eyes surrounded by chocolate 

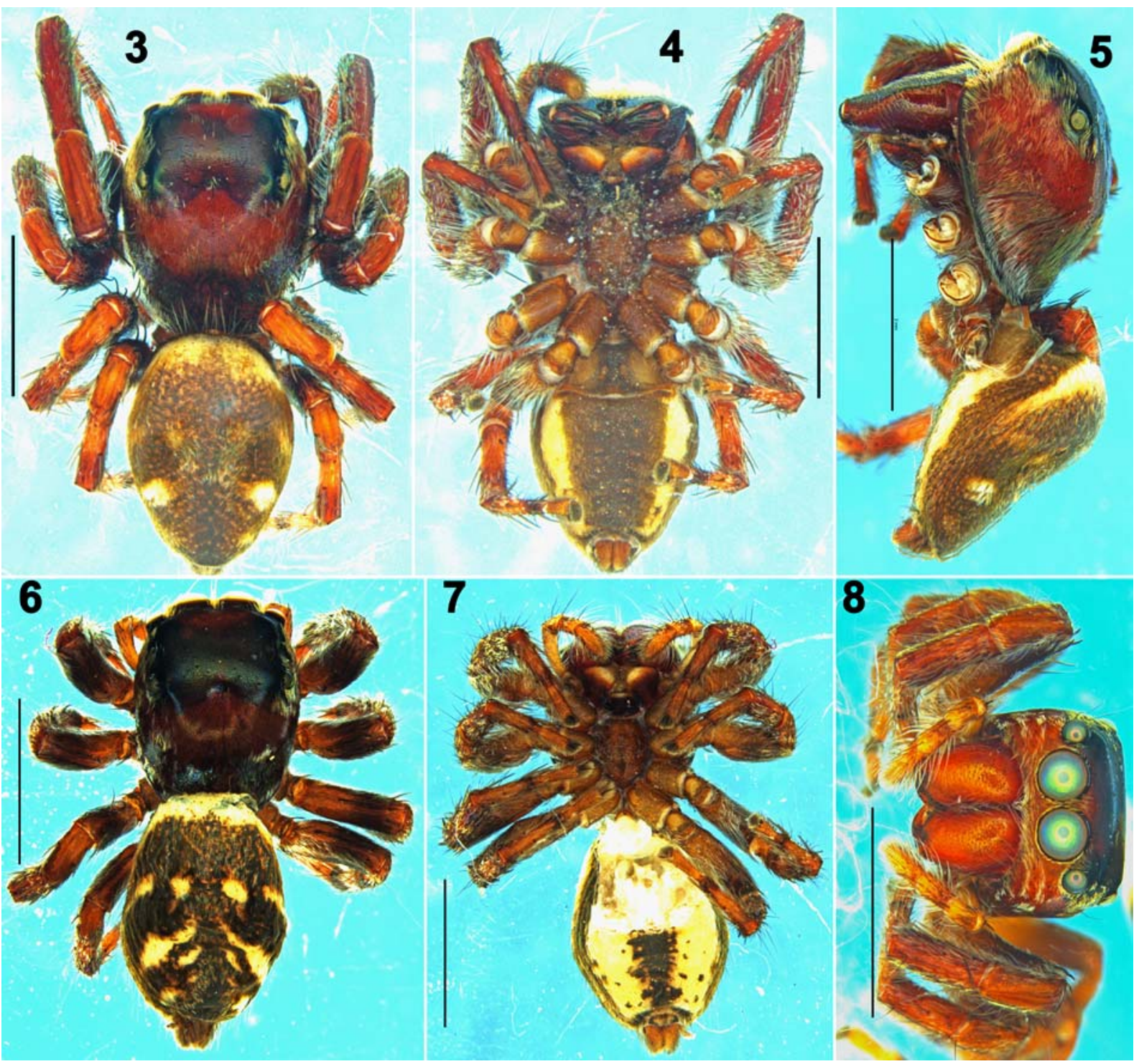

Figs 3-8. Habitus of Carrhotus tholpettyensis sp.n., holotype male (3-5), paratype female (6-8): 3,6 - dorsal view; 4, 7 - ventral view; 5 - lateral view; 8 - carapace, frontal view. Scale bars: $2 \mathrm{~mm}$.

Рис. 3-8. Габитус Carrhotus tholpettyensis sp.n., голотип-самец (3-5), паратип-самка (6-8): 3, 6 - вид сверху; 4, 7 - вид снизу; 5 - вид сбоку; 8 - головогрудь, вид спереди. Масштаб: 2 мм.

white setae (Fig 3). Clypeus low, light reddish brown, covered with long white setae. Chelicerae long, robust, dark reddish brown (Fig 5), promargin with two teeth and retromargin with a single tooth. Labium and endites reddish brown, with paler tips (Fig 4). Sternum yellowish brown, covered with grey hairs (Fig 4). Abdomen elongate, ovoid, brownish, with numerous pale yellowish speckles; anterior region with a pale yellow streak, medially with four pale yellowish transversely arranged patches, and its posterior half with a pair of yellowish round lateral conspicuous patches (Figs 3, 5); venter brownish, with two lateral broad creamy white longitudinal stripes that run from epigastric furrow to posterior end (Fig 4). Legs reddish brown, covered with numerous bristles, hairs and spines (Figs 3, 4). Spinnerets light brown, covered with hairs (Figs 4, 5). Palp elongate, dark reddish brown, tibia and cymbium with long dark brown bristles; RTA short, claw-like with curved tip; tegulum elongate with a posterior lobe; embolus nearly cone-shaped, situated anteriorly on bulbus, with a pointed tip directed at 11 o' clock (Figs 9-11, 14-15).

FEMALE (paratype; Figs 1, 6-8, 12-13, 16-17): Measurements. Body length 5.37. Carapace length 2.50, width (at the middle) 1.98. Abdomen length 3.01, width (at the middle) 1.91. Ocular area length 1.19, width 1.77. Eye diameters: AME 0.51, ALE 0.26, PME 0.05, PLE 0.24. Eye interdistances: AME-ALE 0.09, PME-PME 1.60, ALEALE 1.19, PME-PLE 0.27, PLE-PLE 1.50, ALE-PLE 0.73, AME-AME 0.05. Clypeus height 0.16. Length of chelicera 1.07. Measurement of palp and legs: palp 2.00 [0.76, 0.26, $0.39,0.59]$, leg I $4.29[1.37,0.64,1.01,0.76,0.51]$, II 3.75 $[1.27,0.60,0.79,0.53,0.56]$, III $4.33[1.58,0.60,0.82$, $0.71,0.62]$, IV $4.35[1.45,0.61,0.92,0.79,0.58]$. Leg 


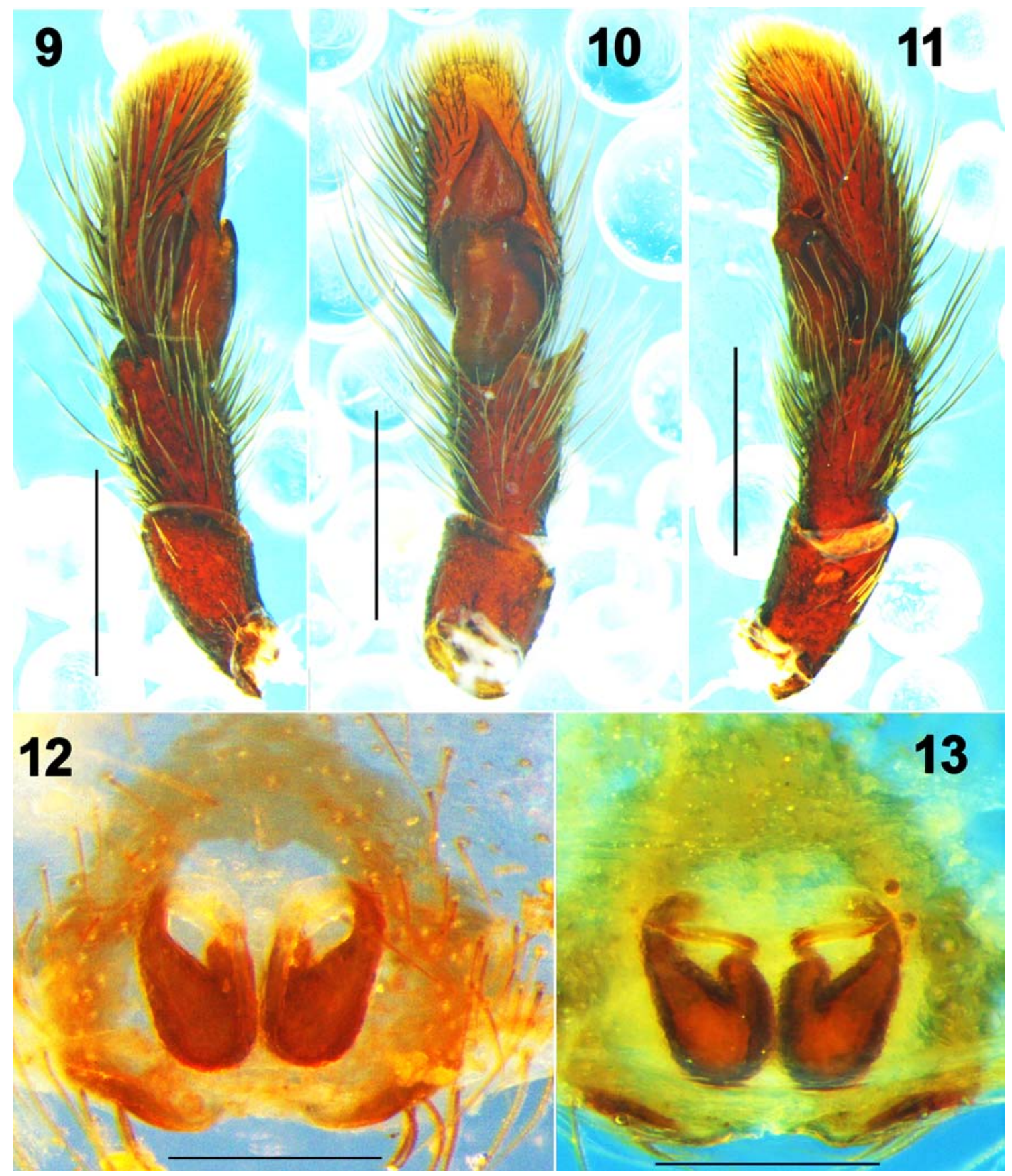

Figs 9-13. Copulatory organs of Carrhotus tholpettyensis sp.n.: 9 - left male palp, prolateral view; 10 - ditto, ventral view, $11-$ ditto, retrolateral view; 12 - epigyne ventral view; 13 - vulva, dorsal view. Scale bars: $0.5 \mathrm{~mm}(9-11), 0.2 \mathrm{~mm}(12-13)$.

Рис. 9-13. Копулятивные органы Carrhotus tholpettyensis sp.n.: 9 - левая пальпа самца, вид сбоку-спереди; 10 - то же, вид снизу, 11 - то же, вид сбоку-сзади; 12 - эпигина, вид снизу; 13 - вульва, вид сверху. Масштаб: 0,5 мм (9-11), 0,2 мм (12-13).

formula: 4312. Leg spination: femur I-IV pl 2 rl 2 do 3; patella I-IV pl $1 \mathrm{rl} 1$; tibia I-II pl 3 rl 3 plv 3 rlv 3, III-IV pl 3 rl 3 rlv 2 plv 2; metatarsus I-IV pl 2 rl 2 rlv 2 plv 2 ; tarsus I-IV spineless. In all respects as the male except as follows: slightly smaller than the male; carapace dark reddish brown; chelicerae shorter; abdomen dark brown, its anterior margin with a conspicuous yellow stripe, medial transverse patches are better visible, posterior middle region with pairs of long and short transversely arranged stripes, and posterior tip with a pair of lateral yellow spots. Venter creamy white, with medial longitudinal broad dark brown stripes. Legs reddish orange. Palp yellowish brown. Epigyne simple, covered with long light brown hairs; copulatory openings located almost in the middle, region near the opening weakly sclerotized; copulatory ducts diverging laterally; spermathecae nearly as hockey stick heads, close to each other; fertilization ducts long, oriented laterally, situated at the anterior region of spermathecae (Figs 12-13, 16-17). 

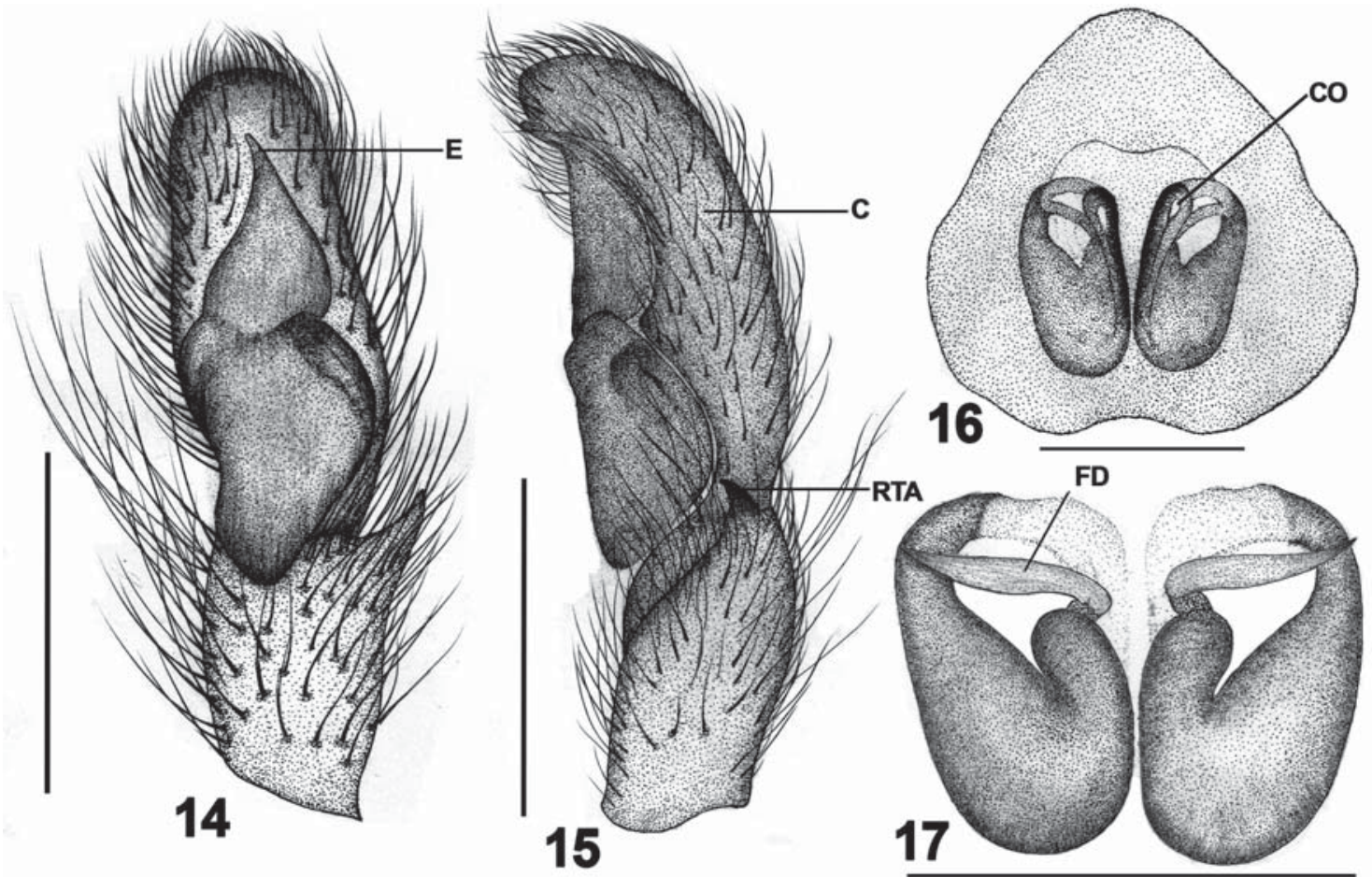

Figs 14-17. Copulatory organs of Carrhotus tholpettyensis sp.n.: 14 - left male palp, ventral view; 15 - ditto, retrolateral view; 16 epigyne, ventral view; 17 - vulva, dorsal view. Scale bars: $0.5 \mathrm{~mm}(14-15), 0.2 \mathrm{~mm}(16-17)$.

Рис. 14-17. Копулятивные органы Carrhotus tholpettyensis sp.n.: 14 - левая пальпа самца, вид снизу; 15 — то же, вид сбокусзади; 16 - эпигина, вид снизу; 17 - вульва, вид сверху. Масштаб: 0,5 мм (14-15), 0,2 мм (16-17).

DISTRIBUTION. India (Kerala) and Sri Lanka [Prószyński, 2009: sub: C. viduus; present data].

Carrhotus viduus (C.L. Koch, 1846) Map.

Plexippus viduus C.L. Koch, 1846: 104, fig. 1166
Carrhotus viduus: Caleb et al., 2020: 61, figs 57-73, 76-78, $80-82$.

For a complete list of taxonomic references see WSC [2021].

MATERIAL. INDIA: $20^{7} O^{7}, 1$ (CATE, 8712), Kerala, Wayanad District, Sulthan Bathery Range, the Wayanad Wildlife Sanctuary $\left(11^{\circ} 43^{\prime} 54.5^{\prime \prime} \mathrm{N}, 76^{\circ} 20^{\prime} 18.5^{\prime \prime} \mathrm{E}\right), 896 \mathrm{~m}$ a.s.1., 14.03 .2017 , P.P. Sudhin \& K.S. Nafin.

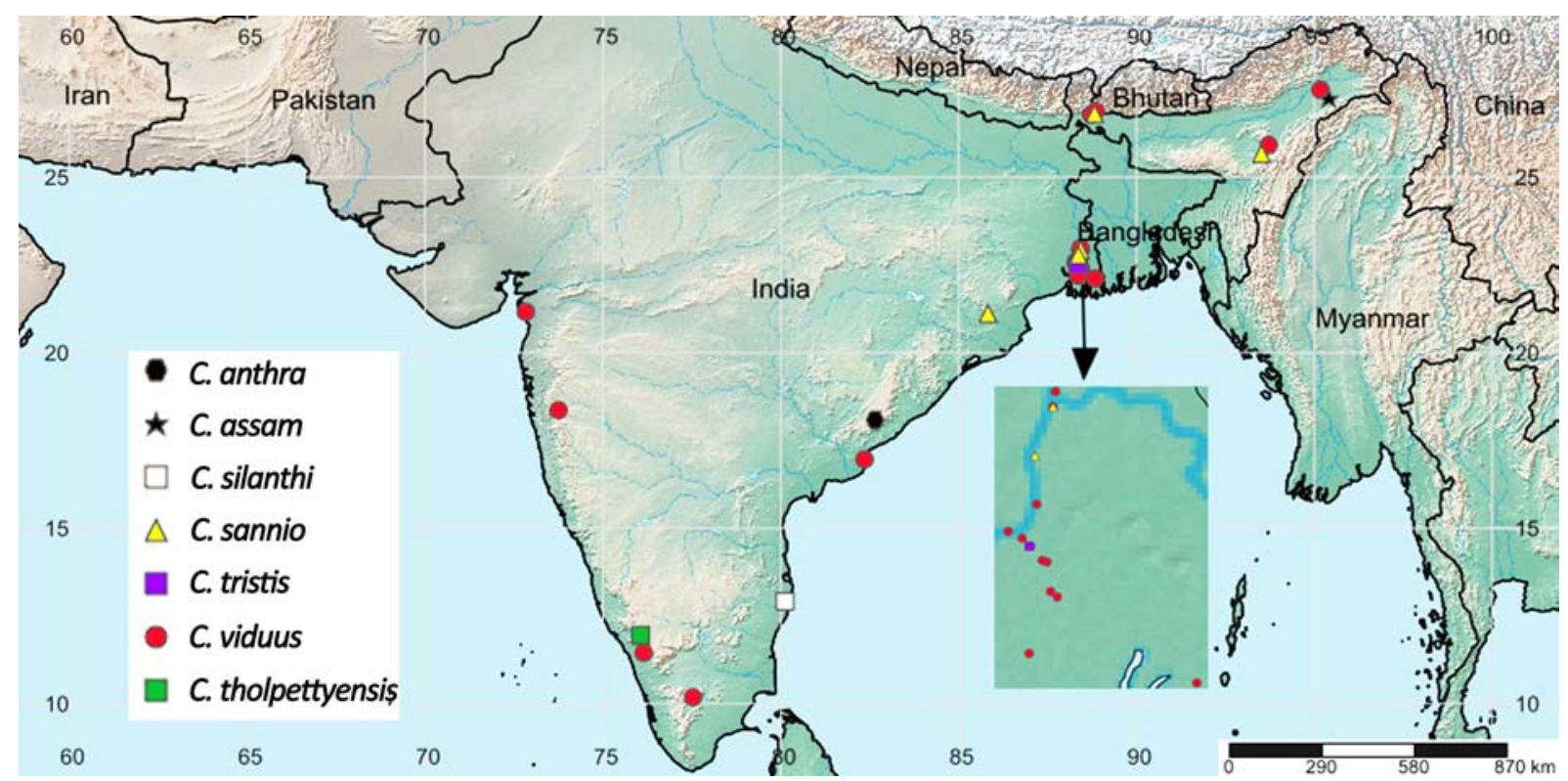

Map. Collecting localities of the Indian Carrhotus species.

Карта. Точки находок индийских видов Carrhotus. 
DISTRIBUTION. Iran, India to China [WSC, 2021], Kerala (a new regional record) (Map).

Acknowledgements. We are grateful to Rev. Fr. Dr Jolly Andrews, Principal, Christ College (Autonomous), Irinjalakuda, Kerala for providing us with all the facilities needed to undertake this work. The authors are grateful to $\mathrm{Mr}$ Dhanesh Kumar P., Wildlife Warden, and the field staff of the Wayanad Wildlife Sanctuary, especially to Mr Krishnadas K. Rajan, Assistant Wildlife Warden, Mr Suresh Thenarambath, Forester and $\mathrm{Mr} \mathrm{Appu}$, Field watcher for their hospitality and support in the field. This study was funded by the Science \& Engineering Research Board (SERB) DST, New Delhi, under the Young Scientist Research Project: No. SB/YS/LS-86/2013. The first author wishes to cordially thank the UGC for its financial support by means of the NFSC. We are grateful to Dr Dmitri V. Logunov of the Manchester Museum (UK) for his suggestions and editorial support which improved the manuscript greatly.

\section{References}

Bosselaers J., Jocqué J. 2000. Studies in Corinnidae: transfer of four genera and description of the female of Lessertina mutica Lawrence 1942 // Tropical Zoology. Vol.13. P.305-325.

Caleb J.T.D., Bera C., Acharya S. 2020. New species and synonymies in the genus Carrhotus Thorell, 1891 from India (Aranei: Salticidae: Salticini) // Arthropoda Selecta. Vol.29. No.1. P.5166. doi:10.15298/arthsel.29.1.04
Jastrzebski P. 2009. Salticidae from the Himalaya. New species of the genus Carrhotus Thorell, 1891 (Araneae: Salticidae) // Genus. Vol.20. No.3. P.533-537.

Koch C.L. 1846. Die Arachniden. Nürnberg: J.L. Lotzbeck. Bd.13, 234 S.; Bd.14, 88 S.

Myers N., Mittermeier R.A., Mittermeier C.G., da Fonseca G.A.B., Kent J. 2000. Biodiversity hotspots for conservation priorities // Nature. Vol.403. P.853-858.

Peng X.J., Xie L.P., Xiao X.Q., Yin C.M. 1993. Salticids in China (Arachnida: Araneae). Hunan Normal University Press. 270 pp.

Prószyński J. 1992. Salticidae (Araneae) of India in the collection of the Hungarian National Natural History Museum in Budapest // Annales Zoologici, PAN. Vol.44. No.9. P.165-277.

Prószyński J. 2009. Redescriptions of 16 species of Oriental Salticidae (Araneae) described by F. Karsch, E. Keyserling and C.L. Koch, with remarks on some related species // Arthropoda Selecta. Vol.18. No.3-4. P.153-168.

Reiskind J. 1969. The spider subfamily Castianeirinae of North and Central America (Araneae, Clubionidae) // Bulletin of the Museum of Comparative Zoology. Vol.138. P.163-325.

Shorthouse D.P. 2010. SimpleMappr, an online tool to produce publication-quality point maps. Available from http:// www. simplemappr.net (accessed 20 June 2021).

Thorell T. 1891. Spindlar från Nikobarerna och andra delar af södra Asien // Kongliga Svenska Vetenskaps-Akademiens Handlingar. Bd.24. H.2. S.1-149.

WSC 2021. World Spider Catalog. Version 22.5. Natural History Museum Bern, online at http://wsc.nmbe.ch, accessed on 5 August 2021. doi: $10.24436 / 2$.

Responsible editor D.V. Logunov 